\title{
Inflation and Stock Returns II
}

\author{
Samih Antoine Azar ${ }^{1}$ \\ ${ }^{1}$ Faculty of Business Administration \& Economics, Haigazian University, Beirut, Lebanon \\ Correspondence: Samih Antoine Azar, Faculty of Business Administration \& Economics, Haigazian University, \\ Mexique Street, Kantari, Beirut, Lebanon. Tel: 961-134-9230. E-mail: samih.azar@haigazian.edu.lb
}

Received: September 24, 2013

Accepted: November 7, $2013 \quad$ Online Published: December 23, 2013

doi:10.5539/ijef.v6n1p208

URL: http://dx.doi.org/10.5539/ijef.v6n1p208

\begin{abstract}
The purpose of this paper is to re-examine the relation between US stock returns, as exemplified by the S\&P 500 returns, and the US inflation rate. Recent research finds out no significant relation, whether positive or negative. This paper allows for an endogenous calendar break, in the first instance, and a Markov switching regression with two regimes, in the second instance. The empirical evidence points to the conclusion that the relation between US stock returns and inflation undergoes a shift. In one regime, and in one subsample, the relation is negative and statistically significant, and in the other regime, and in the other subsample, the relation is statistically insignificant. The paper argues that there is no theoretical reason for such a finding. Further scrutiny shows that the results are driven by both conditional heteroscedasticity of the regression residuals, and a non-stationary statistical behavior of the inflation variable. The conclusion therefore remains strong that inflation is irrelevant for stock returns.
\end{abstract}

Keywords: S\&P 500, inflation rate, constant growth dividend model, cost of equity, baa corporate bond yield, calendar breaks, Markov switching regressions, EGARCH, conditional heteroscedasticity, non-stationarity

\section{Introduction}

When stock returns are regressed on the inflation rate the slope coefficient is invariably negative and statistically significantly different from zero. This empirical regularity dates back to the 1970s (Fama \& Schwert, 1977), but prevails to the present as recent statistical evidence, reproduced in this paper, shows. This runs against the Fisher hypothesis (Fisher, 1930). This hypothesis states that nominal stock returns and other asset and financial returns should increase proportionately with the inflation rate, or, at least, with the expected inflation rate. Researchers have competed in providing a theoretical explanation for the stylized fact of a negative relation between inflation and stock returns. Modigliani and Cohn (1979) consider that investors suffer from money illusion: real cash flows are discounted at nominal rates. When inflation is higher the discount rate is higher, but, because cash flows are not adjusted for inflation, this leads to lower stock prices. Feldstein (1980) notes that, with higher inflation, firms face a higher marginal tax rate because of bracket creep and, as a result, their after-tax profits are lower and consequently stock prices are lower. Fama (1981) starts from the money demand relation in which the price level is inversely proportional to aggregate output. Since higher stock prices indicate higher output, then stock returns and inflation will also be negatively related. Geske and Roll (1983) propose a reverse causality relation. Higher stock prices are a prelude to higher output, which increases taxes, reduces the budget deficit and slows the monetization of the public debt, and this produces lower inflation. Finally, higher inflation may coincide with a depreciation of the domestic currency, at least if Purchasing Power Parity holds, and this has a dampening effect on the stock market.

Azar (2010) is amongst the first to dispute such a negative relation. He argues that stock returns depend on the discounted value of future cash flows. If inflation is higher both anticipated nominal cash flows are higher and the discount rate is higher, the latter because of the existence of an inflation premium. The result is that the present value of cash flows remains unchanged. Azar (2010) finds statistical evidence in support of his argument. The said negative relation dissipates when a fundamental variable is added to the regressions. This variable is nothing else but the change in the cost of equity. Its inclusion in the regressions is justified theoretically by the constant dividend growth model of stock prices.

This paper goes one step further. If an endogenous calendar break is allowed for, or if a Markov switching regression with two regimes is estimated, then there is strong empirical evidence of a shift in the relation between 
stock returns, the change in the cost of equity, and the inflation rate. In one regime, and in one subsample, the coefficient on inflation is negative and statistically significant, while in the other regime, and the other subsample, the negative impact of inflation disappears and is hence statistically insignificant. This shift in the relation is nevertheless a puzzle because there is no theoretical reason for it. Further scrutiny finds that the statistically significant results are driven by conditional heteroscedasticity of the regression residuals, and the fact that the inflation rate follows a non-stationary statistical behavior. Therefore, the evidence remains strong that inflation does not explain significantly stock returns, even if allowance is made for shifts.

The paper is organized as follows. In the second section a theoretical methodology is introduced. In section 3 the empirical results are presented. Section 3 has five major parts. The first part dwells on the prima facie evidence on the negative relation between stock returns and inflation. The second part discloses the prima facie evidence on the irrelevance of inflation in a stock return regression, when the change in the cost of equity is included in the regressions. The third part reveals evidence that the inflation/stock relation is subject to shifts. The fourth part reports evidence of shifts in the more general relation between inflation, stock returns, and the change in the cost of equity. The fifth and last part presents evidence on the non-stationarity of the inflation rate, and the subsequent bias in standard errors. The final section summarizes and concludes.

\section{The Theory}

The model in this paper borrows from a relation developed by Williams $(1938)$ and Gordon $(1959 ; 1962)$ and which is:

$$
P_{t}=\frac{D_{t+1}}{(k-g)}=\frac{(1+g) D_{t}}{(k-g)}
$$

where $P_{t}$ is this period's stock price, $D_{t+1}$ is next period's dividend, $D_{t}$ is the current dividend, $k$ is the cost of equity, $g$ is the constant growth rate in dividends, and measures also the capital gain's yield, and $t$ is the time period.

Taking a Taylor series expansion of equation (1) one gets:

$$
d(P)=\frac{\partial P}{\partial t} d(t)+\frac{\partial P}{\partial k} d(k) \Rightarrow d(P)=\frac{\partial P}{\partial t} d(t)-\frac{D_{1}}{(k-g)^{2}} d(k) \Rightarrow \frac{d(P)}{P}=\frac{\partial P}{P \partial t} d(t)-\frac{1}{(k-g)} d(k)
$$

The first term on the RHS of equation (2) is the drift. The second term or the fundamental variable in this equation is $k$, and it enters in first-difference, i.e. $(d(k))$, in explaining the relative change in stock prices (Azar, 2010). The proportionality factor is the negative inverse of the dividend yield, $(k-g)=D_{t+1} / P_{t}$, which happens also to be the (modified) duration (Hallerbach, 2003; Baz and \& Chacko, 2004).

Using the following approximations which are close to equality with monthly data:

$$
\frac{d(P)}{P} \approx \frac{\Delta(P)}{P} \approx \Delta(\log (P))
$$

where log is the natural logarithm, and $\Delta$ is the first-difference operator, then equation (2) becomes:

$$
\Delta(\log (P)) \approx \mu-\frac{1}{(k-g)} \Delta(k) \approx \mu+\beta \Delta(k)+\varepsilon
$$

Where $\mu$ and $\beta$ are regression coefficients and $\varepsilon$ is the regression residual. Regression equation (4) does not include any variable related to inflation. Therefore it justifies the irrelevance of inflation. However part of the empirical analysis will include the inflation rate in the regression although the author cannot find a valid account about why inflation should be important statistically in a given regime, or a given subsample, but not otherwise.

\section{The Empirical Results}

The data on the US Consumer Price Index for all items and on the S\&P 500 stock index are taken from the web site of the Federal Reserve Bank of Saint Louis. These two variables are adjusted by calculating the change in their natural logs. The cost of equity is replaced by the baa corporate bond yield obtained also from the same source. This variable is divided by 1200 in order to obtain monthly decimal figures. The change in this variable is included in the regressions. All the data is monthly and spans the period from January 1957 to July 2013. The statistical software used in this paper is EViews 8 (2013).

Table 1 presents the prima facie evidence on the significant and negative relation between the S\&P $500 \log$ returns and the inflation rate. Two econometric specifications are adopted: Ordinary Least Squares (OLS), and 
exponential GARCH, or EGARCH. See Nelson (1991) on the latter. The first specification is in conformity to the extant empirical research on the subject, while the second specification allows for a leverage effect (Black, 1976; Christie, 1982). This effect is found to be statistically significant and implies that a negative shock to stock returns, which increases leverage, increases also the conditional variance. The two estimates of the impact of inflation on stock returns are immaterially different in the two specifications: -1.3781 (OLS) and -1.3903 (EGARCH), with absolute t-statistics of 2.6487 and 2.5953 respectively. These two estimates are insignificantly different from -1 , with respective absolute t-statistics of 0.7267 and 0.7285 . Hence a $1 \%$ inflation rate reduces stock returns by $1 \%$. The intercepts measure the expected average equity return. On an annualized basis this return is equal to $12.327 \%$ and $11.449 \%$ respectively, with t-statistics of 4.1860 and 4.1829 . These estimates are reasonable. Nonetheless the OLS regression residuals suffer from conditional heteroscedasticity, although high-order serial correlation is absent. The standardized residuals of the EGARCH model are well-behaved: there is no evidence for serial correlation or conditional heteroscedasticity. As expected, the EGARCH model is preferred by the three information criteria: the Akaike, the Schwarz, and the Hannan-Quinn information criteria. The evidence in Table 1 is therefore strong about the prima facie negative relation between US inflation and US stock returns. This evidence is called prima facie because the regressions omit one important variable which is the change in the cost of equity.

Table 1. Prima facie evidence on the negative relation between inflation and stock returns

\begin{tabular}{|c|c|c|}
\hline Variable & $\begin{array}{c}\text { Ordinary Least Squares } \\
\text { (OLS) }\end{array}$ & EGARCH \\
\hline $\begin{array}{l}\text { Constant } \\
\Delta(\log (c p i))\end{array}$ & $\begin{array}{c}0.009687(4.185988) \\
-1.378120(2.648736)\end{array}$ & $\begin{array}{c}\text { Conditional mean equation: } \\
0.009033(4.182868) \\
-1.390273(2.595315)\end{array}$ \\
\hline $\begin{array}{c}\text { Constant } \\
\text { ABS(RESID }(-1)) /(\operatorname{GARCH}(-1))^{\wedge} 0.5 \\
\operatorname{RESID}(-1) /(\operatorname{GARCH}(-1))^{\wedge} 0.5 \\
\operatorname{LOG}(\operatorname{GARCH}(-1))\end{array}$ & & $\begin{array}{c}\text { Conditional variance equation } \\
-0.827130(4.392998) \\
0.226390(3.266920) \\
-0.110455(1.975574) \\
0.898009(34.96270)\end{array}$ \\
\hline Adjusted R-Square & 0.008808 & 0.008544 \\
\hline Log likelihood & 1178.448 & 1214.096 \\
\hline Akaike information criterion & -3.470347 & -3.563704 \\
\hline Schwarz information criterion & -3.457016 & -3.523712 \\
\hline Hannan-Quinn criterion & -3.465186 & -3.548222 \\
\hline Durbin-Watson statistic & 1.871170 & 1.870543 \\
\hline \multicolumn{3}{|l|}{ Ljung-Box Q-statistics: } \\
\hline $\mathrm{K}=6$ & 0.110 & 0.343 \\
\hline $\mathrm{K}=12$ & 0.375 & 0.809 \\
\hline $\mathrm{K}=24$ & 0.703 & 0.848 \\
\hline \multicolumn{3}{|l|}{ Ljung-Box $Q^{2}$-statistics: } \\
\hline $\mathrm{K}=6$ & 0.000 & 0.977 \\
\hline $\mathrm{K}=12$ & 0.000 & 0.927 \\
\hline $\mathrm{K}=24$ & 0.000 & 0.935 \\
\hline
\end{tabular}

Notes: The dependent variable is the S\&P $500 \log$ return $\Delta(\log (S P 500))$, and the independent variable is the change in the log of the all items US CPI $\Delta(\log (c p i))$.

Absolute t-statistics in parenthesis. The actual p-values of the Ljung-Box Q-statistics and $Q^{2}$-statistics are reported (Ljung and Box, 1978) with $\mathrm{K}$ as the lag length. These statistics are respectively for the residuals and their squares for the OLS regression, and are for the standardized residuals and their squares for the EGARCH regression.

Table 2 presents the same two models, OLS and EGARCH, with the inclusion of the change in the cost of equity, as proxied by the change in the baa corporate bond yield. The evidence is strong that the impact of inflation disappears: the absolute t-statistics on the inflation impact are now 1.5060 and 1.6561 . The change in the baa corporate bond yield has negative coefficients, as expected. The two estimates for these coefficients measure the modified duration which is respectively 51.495 years for the OLS regression, and 46.676 years for the EGARCH model. The inverse of these two duration estimates measure the market dividend yield, which is $1.942 \%$ and $2.142 \%$ respectively, figures that are relatively on the low side. The intercepts measure the expected average 
equity return. On an annualized basis this return is equal to $9.902 \%$ and $8.938 \%$ respectively, with t-statistics of 3.4407 and 3.2822 respectively. These estimates are reasonable. Nonetheless the OLS regression residuals suffer from conditional heteroscedasticity, although high-order serial correlation is absent. However, the standardized residuals of the EGARCH model are well-behaved: there is no evidence for serial correlation or conditional heteroscedasticity. As expected, the EGARCH model is preferred by the three information criteria: the Akaike, the Schwarz, and the Hannan-Quinn information criteria. The evidence in Table 2 is therefore strong about the spurious negative relation between US inflation and US stock returns. When the change in the cost of equity is added to the inflation regressions, the impact of inflation dissipates. This is in conformity to Azar (2010). This evidence is called prima facie because the regressions do not allow for shifts. The next step is to allow for such shifts.

Table 2. Prima facie evidence on the irrelevance of inflation on stock returns

\begin{tabular}{|c|c|c|}
\hline variable & $\begin{array}{c}\text { Ordinary least squares } \\
\text { (OLS) }\end{array}$ & EGARCH \\
\hline $\begin{array}{c}\text { Constant } \\
\Delta(\log (\text { cpi })) \\
\Delta(\mathrm{baa})\end{array}$ & $\begin{array}{c}0.007868(3.440706) \\
-0.782937(1.506044) \\
-51.49535(5.613310)\end{array}$ & $\begin{array}{c}\text { Conditional mean equation: } \\
0.007134(3.282201) \\
-0.751248(1.656074) \\
-46.67585(5.709326)\end{array}$ \\
\hline $\begin{array}{c}\text { Constant } \\
\text { ABS(RESID }(-1)) /(\operatorname{GARCH}(-1))^{\wedge} 0.5 \\
\text { RESID }(-1) /(\operatorname{GARCH}(-1))^{\wedge} 0.5 \\
\text { LOG(GARCH(-1)) }\end{array}$ & & $\begin{array}{c}\text { Conditional variance equation: } \\
-0.701715(2.854984) \\
0.228375(3.244221) \\
-0.066903(3.095312) \\
0.918587(27.91986) \\
\end{array}$ \\
\hline Adjusted R-Square & 0.051610 & 0.050964 \\
\hline Log likelihood & 1193.914 & 1226.298 \\
\hline Akaike information criterion & -3.513021 & -3.596750 \\
\hline Schwarz information criterion & -3.493024 & -3.550092 \\
\hline Hannan-Quinn criterion & -3.505279 & -3.578688 \\
\hline Durbin-Watson statistic & 1.967552 & 1.961769 \\
\hline \multicolumn{3}{|l|}{ Ljung-Box Q-statistics: } \\
\hline $\mathrm{K}=6$ & 0.369 & 0.555 \\
\hline $\mathrm{K}=12$ & 0.718 & 0.931 \\
\hline$K=24$ & 0.911 & 0.981 \\
\hline \multicolumn{3}{|l|}{ Ljung-Box $Q^{2}$-statistics: } \\
\hline $\mathrm{K}=6$ & 0.000 & 0.974 \\
\hline $\mathrm{K}=12$ & 0.000 & 0.959 \\
\hline $\mathrm{K}=24$ & 0.000 & 0.969 \\
\hline
\end{tabular}

Note: The dependent variable is the S\&P $500 \log$ return $\Delta(\log S P 500)$, and the independent variables are the change in the log of the all items US CPI $\Delta(\log (p p i))$, and the change in the baa corporate bond yield divided by $1200 \Delta($ baa).

See notes under Table 1.

To identify shifts two econometric models are adopted. The first is for least squares with breakpoints that are estimated sequentially from the data (Bai, 1997; Bai \& Perron, 1998). Heterogeneous error distributions across breaks are assumed. As much as five breaks are allowed for. The second model is a Markov switching regression with two regimes, with regime specific error variances. Table 3 presents the results of the regressions between stock returns and inflation, omitting the change in the baa corporate bond yield, while Table 4 presents the results that include the change in this yield. 
Table 3. Shifts in the relation between $\Delta(\log (S P 500))$ and $\Delta(\log ($ cpi $))$

\begin{tabular}{|c|c|c|c|}
\hline \multicolumn{2}{|c|}{ Least Squares with a calendar breakpoint } & \multicolumn{2}{|c|}{ Markov switching regressions } \\
\hline First Sample & $\begin{array}{c}1957.2-1974.9 \\
\mathrm{~N}=212\end{array}$ & Regime \# 1 & \\
\hline Constant & $\begin{array}{c}0.013367 \\
(3.832852)\end{array}$ & Constant & $\begin{array}{c}0.017469 \\
(7.085596)\end{array}$ \\
\hline Coefficient on $\Delta(\log (c p i))$ & $\begin{array}{l}-4.112866 \\
(4.748701)\end{array}$ & $\begin{array}{c}\text { Coefficient on } \Delta(\log (c p i)) \\
\text { LOG(SIGMA) }\end{array}$ & $\begin{array}{c}-2.464819 \\
(3.906780) \\
-3.417274 \\
(55.89150)\end{array}$ \\
\hline Second sample & $\begin{array}{c}1974.10-2013.7 \\
\mathrm{~N}=466\end{array}$ & Regime \# 2 & \\
\hline Constant & $\begin{array}{c}0.008697 \\
(2.948988)\end{array}$ & Constant & $\begin{array}{l}-0.019277 \\
(1.574937)\end{array}$ \\
\hline Coefficient on $\Delta(\log (c p i))$ & $\begin{array}{l}-0.506809 \\
(0.795069)\end{array}$ & Coefficient on $\Delta(\log (c p i))$ & $\begin{array}{c}1.240796 \\
(0.795682) \\
-2.701264 \\
(27.94502)\end{array}$ \\
\hline Adjusted R-Square & 0.023539 & & \\
\hline Log likelihood & 1184.528 & Log likelihood & 1221.161 \\
\hline Durbin-Watson statistic & 1.908881 & Durbin-Watson statistic & 1.928234 \\
\hline Akaike Information criterion & -3.482384 & Akaike Information criterion & -3.578647 \\
\hline Schwarz information criterion & -3.455722 & Schwarz information criterion & -3.525324 \\
\hline $\begin{array}{l}\text { Hannan-Quinn information } \\
\text { criterion }\end{array}$ & -3.472062 & $\begin{array}{l}\text { Hannan-Quinn information } \\
\text { criterion }\end{array}$ & -3.558004 \\
\hline Ljung-Box Q-statistics: & & Ljung-Box Q-statistics: & \\
\hline $\mathrm{k}=6$ & 0.151 & $\mathrm{k}=6$ & 0.198 \\
\hline $\mathrm{k}=12$ & 0.435 & $\mathrm{k}=12$ & 0.531 \\
\hline $\mathrm{k}=24$ & 0.770 & $\mathrm{k}=24$ & 0.851 \\
\hline Ljung-Box $\mathrm{Q}^{2}$-statistics: & & Ljung-Box $\mathrm{Q}^{2}$-statistics: & \\
\hline $\mathrm{k}=6$ & 0.000 & $\mathrm{k}=6$ & 0.820 \\
\hline $\mathrm{k}=12$ & 0.000 & $\mathrm{k}=12$ & 0.526 \\
\hline$k=24$ & 0.004 & $\mathrm{k}=24$ & 0.771 \\
\hline
\end{tabular}

Notes: In parenthesis are absolute t-statistics. The break type is according to the Bai-Perron tests, with heterogeneous error distributions across breaks. The Markov switching regressions are for two regimes, with regime specific error variances. The actual p-values of the Ljung-Box Q-statistics and $\mathrm{Q}^{2}$-statistics are reported. These statistics are respectively for the residuals and their squares for the breakpoint regression, and are for the standardized residuals and their squares for the switching regression.

The calendar break that is selected by the statistical software is October 1974. This is noteworthy the same break in the regression that excludes the change in the baa corporate bond yield (Table 3, Panel A) and in the regression that includes the change in this yield (Table 4, Panel A). In Table 3, Panel A, two regressions are estimated, one before the break, and the other after the break. It is already known that these regressions are misspecified because they do not include the proxy for the change in the cost of equity. However, for an unknowledgeable researcher, who is interested only in the effect of inflation on stock returns, the evidence points to an empirical fact. This fact is that inflation has a highly significant and negative influence on stock returns for the sample before the break of October 1974, with a t-statistic of -4.7487 , but has a statistically insignificant effect for the sample post this break, with a t-statistic of -0.7951 . Arguably this is surprising. There is no theoretical reason for such a finding. In Table 3, Panel B, a Markov switching model, with two regimes, is estimated. In one regime inflation enters as a statistically significant variable, with a t-statistic of -3.9068 , but in the other regime inflation does not explain significantly stock returns, with a t-statistic of 0.7957 . Again there is no theoretical reason for such a result. 
Table 4. Shifts in the relation between $\Delta(\log (S P 500))$ with $\Delta($ baa $)$, and $\Delta(\log ($ cpi $))$

\begin{tabular}{|c|c|c|c|}
\hline \multicolumn{2}{|c|}{ Least Squares with a calendar breakpoint } & \multicolumn{2}{|c|}{ Markov switching regressions } \\
\hline First Sample & $\begin{array}{c}1957.2-1974.9 \\
\mathrm{~N}=212\end{array}$ & Regime \# 1 & \\
\hline Constant & $\begin{array}{c}0.012291 \\
(3.580041)\end{array}$ & Constant & $\begin{array}{c}0.015566 \\
(6.192698)\end{array}$ \\
\hline Coefficient on $\Delta$ (baa) & $\begin{array}{l}-90.46285 \\
(3.099159)\end{array}$ & Coefficient on $\Delta$ (baa) & $\begin{array}{l}-47.39390 \\
(4.640752)\end{array}$ \\
\hline Coefficient on $\Delta(\log (c p i))$ & $\begin{array}{l}-3.024174 \\
(3.293998)\end{array}$ & $\begin{array}{c}\text { Coefficient on } \Delta(\log (c p i)) \\
\text { LOG(SIGMA) }\end{array}$ & $\begin{array}{c}-2.072169 \\
(2.930770) \\
-3.451795 \\
(68.60677)\end{array}$ \\
\hline Second sample & $\begin{array}{c}1974.10-2013.7 \\
\mathrm{~N}=466\end{array}$ & Regime \# 2 & \\
\hline Constant & $\begin{array}{c}0.006446 \\
(2.203736)\end{array}$ & Constant & $\begin{array}{l}-0.015793 \\
(1.566846)\end{array}$ \\
\hline Coefficient on $\Delta$ (baa) & $\begin{array}{l}-47.33193 \\
(4.696674)\end{array}$ & Coefficient on $\Delta$ (baa) & $\begin{array}{l}-48.96016 \\
(1.777235)\end{array}$ \\
\hline Coefficient on $\Delta(\log (c p i))$ & $\begin{array}{c}0.054128 \\
(0.085241)\end{array}$ & Coefficient on $\Delta(\log (c p i))$ & $\begin{array}{c}1.769520 \\
(1.145391) \\
-2.735460 \\
(29.26330) \\
\end{array}$ \\
\hline Adjusted R-Square & 0.064862 & & \\
\hline Log likelihood & 1200.194 & Log likelihood & 1235.652 \\
\hline Durbin-Watson statistic & 2.005335 & Durbin-Watson statistic & 2.010421 \\
\hline $\begin{array}{l}\text { Akaike Information } \\
\text { criterion }\end{array}$ & -3.522696 & Akaike Information criterion & -3.615493 \\
\hline $\begin{array}{c}\text { Schwarz information } \\
\text { criterion }\end{array}$ & -3.482704 & $\begin{array}{c}\text { Schwarz information } \\
\text { criterion }\end{array}$ & -3.548839 \\
\hline $\begin{array}{l}\text { Hannan-Quinn information } \\
\text { criterion }\end{array}$ & -3.507214 & $\begin{array}{l}\text { Hannan-Quinn information } \\
\text { criterion }\end{array}$ & -3.589690 \\
\hline Ljung-Box Q-statistics: & & Ljung-Box Q-statistics: & \\
\hline $\mathrm{k}=6$ & 0.336 & $\mathrm{k}=6$ & 0.337 \\
\hline $\mathrm{k}=12$ & 0.685 & $\mathrm{k}=12$ & 0.731 \\
\hline $\mathrm{k}=24$ & 0.911 & $\mathrm{k}=24$ & 0.952 \\
\hline Ljung-Box $Q^{2}$-statistics: & & Ljung-Box $Q^{2}$-statistics: & \\
\hline $\mathrm{k}=6$ & 0.000 & $\mathrm{k}=6$ & 0.792 \\
\hline $\mathrm{k}=12$ & 0.000 & $\mathrm{k}=12$ & 0.706 \\
\hline $\mathrm{k}=24$ & 0.000 & $\mathrm{k}=24$ & 0.802 \\
\hline
\end{tabular}

Note: See notes under Table 3.

Table 4 is similar to Table 3 with one difference: the regressions include, besides the inflation rate, the change in the baa corporate bond yield, as a proxy for the change in the cost of equity. As already mentioned, the statistical software selects the same breakpoint as in Table 3. In Panel A of Table 4, and with the sample before the break, inflation has a statistically significant impact on stock returns, with a t-statistic of -3.2940 , while, for the sample after the break, inflation has no significant effect on stock returns, with a t-statistic of 0.08524 . The coefficients on the change in the baa corporate bond yield are statistically significant in both subsamples, before and after the break, with respective t-statistics of -3.0992 and -4.6967 . The modified durations are respectively 90.463 years and 47.332 years. The implied dividend yields are respectively $1.105 \%$ and $2.113 \%$.

Panel B of Table 4 gives the statistical results for the Markov switching regression with two regimes. The coefficient on the inflation rate is statistically significantly different from zero in the first regime, with a t-statistic of -2.9308 , and statistically insignificantly different from zero in the other regime, with a t-statistic of 1.1454. The coefficient on the change in the proxy for the cost of equity is statistically significantly different from zero in the first regime, with a t-statistic of -4.6408 , but is statistically marginally different from zero in the second regime, with a t-statistic of -1.7772 . Here again there is no theoretical reason for having two different regimes except that the first regime is a low-volatility regime, and the other is a high-volatility regime. It is likely 
that these two regimes correspond to the two subsamples identified by the break in October 1974.

Since there is no reason to justify two subsamples and two regimes, with differing statistical significance, the results must be driven by other factors. Further scrutiny shows that the inflation rate follows a non-stationary statistical process in the whole sample, and in the first and older subsample (Table 5). This implies that the coefficients on the inflation rate variable may not follow standard distributions. In a related context Sweeney (1997) has also the same problem with a non-stationary regressor. His simulations find that the coefficient on this regressor follows a distribution that is an average between an asymptotic normal distribution and a Dickey-Fuller distribution. Therefore the standard errors in Tables 3 and 4 are likely to be biased downward.

Table 5. Unit root tests on the inflation rate $\Delta(\log (c p i))$. The null hypothesis is non-stationarity for the two tests

\begin{tabular}{cccc}
\hline & Whole sample: & First subsample: & Second subsample: \\
& January 1957 to & January 1957 to & October 1974 to \\
Unit root test & July 2013 & September 1974 & July 2013 \\
& $\mathrm{N}=679$ & $\mathrm{~N}=213$ & $\mathrm{~N}=466$ \\
\hline Augmented Dickey-Fuller test: & -3.309533 & -1.528491 & -11.94202 \\
Dickey and Fuller (1979) & $(0.0655)$ & $(0.819)$ & $(0.0000)$ \\
\hline ERS Point-optimal test: & 6.535424 & 30.02261 & 0.624791 \\
Elliott, Rothenberg and Stock (1996) & & &
\end{tabular}

Notes: In parenthesis are p-values. The critical values for the ERS point-optimal test for the whole sample and the second subsample are: $6.890000(10 \%), 5.620000(5 \%)$, and $3.960000(1 \%)$. The critical values for the ERS point-optimal test for the first subsample are: 6.861950 $(10 \%), 5.657400(5 \%)$, and $4.044150(1 \%)$.

Table 6. Regressions for the first sub-sample with $\Delta(\log (s S P 500))$ as the dependent variable and inflation $\Delta(\log (c p i))$ and the change in the baa corporate bond yield $\Delta($ baa $)$ as the two independent variables

\begin{tabular}{|c|c|c|}
\hline variable & $\begin{array}{c}\text { Ordinary least squares } \\
\text { (OLS) }\end{array}$ & EGARCH \\
\hline $\begin{array}{c}\text { Constant } \\
\Delta(\log (c p i)) \\
\Delta(\mathrm{baa})\end{array}$ & $\begin{array}{c}0.006079(1.955351) \\
-1.594288(2.054919)\end{array}$ & $\begin{array}{c}\text { Conditional mean equation: } \\
0.007486(2.318007) \\
-1.572802(1.652838) \\
-68.88165(2.606406)\end{array}$ \\
\hline $\begin{array}{c}\text { Constant } \\
\text { ABS(RESID }(-1)) /(\operatorname{GARCH}(-1))^{\wedge} 0.5 \\
\text { RESID }(-1) /(\operatorname{GARCH}(-1))^{\wedge} 0.5 \\
\operatorname{LOG(GARCH}(-1))\end{array}$ & $\begin{array}{l}-0.630796(1.873269) \\
-0.020667(0.290587) \\
-0.219704(3.909627) \\
0.902782(19.40213)\end{array}$ & $\begin{array}{c}\text { Conditional variance equation: } \\
-1.146492(1.832899) \\
-0.014114(0.146501) \\
-0.242204(3.026096) \\
0.828028(8.773489)\end{array}$ \\
\hline Adjusted R-Square & 0.055928 & 0.108694 \\
\hline Log likelihood & 414.0290 & 416.9875 \\
\hline Akaike information criterion & -3.849331 & -3.867807 \\
\hline Schwarz information criterion & -3.754333 & -3.756976 \\
\hline Hannan-Quinn criterion & -3.810935 & -3.823012 \\
\hline Durbin-Watson statistic & 1.705757 & 1.826932 \\
\hline \multicolumn{3}{|l|}{ Ljung-Box Q-statistics: } \\
\hline $\mathrm{K}=6$ & 0.848 & 0.936 \\
\hline $\mathrm{K}=12$ & 0.660 & 0.431 \\
\hline $\mathrm{K}=24$ & 0.731 & 0.371 \\
\hline \multicolumn{3}{|l|}{ Ljung-Box $\mathrm{Q}^{2}$-statistics: } \\
\hline $\mathrm{K}=6$ & 0.903 & 0.875 \\
\hline $\mathrm{K}=12$ & 0.911 & 0.865 \\
\hline$K=24$ & 0.994 & 0.987 \\
\hline
\end{tabular}

Note: See notes under Table 1. 
The major finding for a statistically significant inflation variable hinges on the evidence for the first sub-sample. In both Tables 3 and 4, Panels A, the two regressions, with calendar breaks, suffer from conditional heteroscedasticity. Table 6 reruns the two regressions for the first subsample with an EGARCH process of the conditional variance. The two coefficients on the inflation rate should still follow non-standard distributions. The two t-statistics on the inflation rate variable are respectively -2.0549 and -1.6528 . The second t-statistic, which denotes non-significance, is for the regression that includes the change in the baa corporate bond yield, and hence does not suffer from misspecification. The first t-statistic has a two-tailed p-value of 0.0399 . The critical value for the Dickey-Fuller distribution, at a marginal significance level of 10\%, is -2.5740 (MacKinnon, 1996). At higher significance levels the Dickey-Fuller t-statistic is higher in absolute terms. Since a t-statistic of -2.0549 is so much lower, in absolute values, than the critical Dickey-Fuller t-statistic of -2.5740 , which is for a marginal significance level of $10 \%$, there is reason to believe that this t-statistic also denotes non-significance.

Anyway, and as expected, the EGARCH model is preferred by the three information criteria: the Akaike, the Schwarz, and the Hannan-Quinn information criteria. This is further evidence on the irrelevance of the inflation rate to stock returns. Therefore the evidence overall points to the conclusion that inflation is irrelevant to stock returns whether shifts, such as breaks or different regimes, are allowed for or not.

\section{Summary and Conclusion}

The purpose of this paper is to re-examine the relation between US stock returns, as exemplified by the S\&P 500 returns, and the US inflation rate. Research is unclear about a significant relation between inflation and stock returns. This paper allows for an endogenous calendar break, in the first instance, and a Markov switching regression with two regimes, in the second instance. In addition the regressions are augmented with the inclusion of a proxy for the change in the cost of equity as the theoretical model implies. The empirical evidence points to the conclusion that the relation between US stock returns and inflation undergoes a shift. In one regime, and in one subsample, the relation is negative and statistically significant, and in the other regime, and in the other subsample, the relation is statistically insignificant. There is no theoretical reason for such a differential finding. Further scrutiny shows that the results are driven by both conditional heteroscedasticity of the regression residuals, and a non-stationary statistical behavior of the inflation variable. When the regressions are adjusted for these two econometric problems, the conclusion becomes strong that inflation is irrelevant for stock returns. Therefore allowance for shifts, like calendar breaks and two regimes, does not change the main conclusion of the irrelevance of inflation to stock returns.

\section{References}

Azar, S. A. (2010). Inflation and stock returns. International Journal of Accounting and Finance, 2(3/4), 254274. http://dx.doi.org/10.1504/IJAF.2010.034399

Bai, J. (1997). Estimating multiple breaks one at a time. Econometric Theory, 13, 315-352. http://dx.doi.org/10.1017/S0266466600005831

Bai, J., \& Perron, P. (1998). Estimating and testing linear models with multiple structural changes. Econometrica, 66, 47-78. http://dx.doi.org/10.2307/2998540

Baz, J., \& Chacko, G. (2004). Financial derivatives, pricing, applications, and mathematics. Cambridge: Cambridge University Press. http://dx.doi.org/10.1017/CBO9780511806643

Black, F. (1976). Studies in stock price volatility changes. Proceedings of the American Statistical Association, Business and Economics Statistics Section, 177-181.

Christie, A. A. (1982). The stochastic behavior of common stock variance: Value, leverage and interest rate effects. Journal of Financial Economics, 10, 407-432. http://dx.doi.org/10.1016/0304-405X(82)90018-6

Dickey, D. A., \& Fuller, W. A. (1979). Distribution of the estimators for autoregressive time series with a unit root. Journal of the American Statistical Association, 74, 427-431.

Elliott, G., Rothenberg, T. J., \& Stock, J. H. (1996). Efficient tests for an autoregressive unit root. Econometrica, 64(4), 813-836. http://dx.doi.org/10.2307/2171846.

E-Views 8. (2013). Irvine. CA: IHS Global Inc.

Fama, E. (1981). Stock returns, real activity, inflation, and money. American Economic Review, 71(4), 1089-1108.

Fama, E., \& Schwert, G. W. (1977). Asset returns and inflation. Journal of Financial Economics, 5, 115-146. http://dx.doi.org/10.1016/0304-405X(77)90014-9

Feldstein, M. (1980). Inflation and the stock market. American Economic Review, 70(5), 839-847. 
Fisher, I. (1930). The theory of interest. New York: Mcmillan.

Geske, R., \& Roll, R. (1983). The fiscal and monetary linkage between stock returns and inflation. Journal of Finance, 38(1), 1-33. http://dx.doi.org/10.1111/j.1540-6261.1983.tb03623.x

Gordon, M. (1959). Dividends, earnings and stock prices. Review of Economics and Statistics, 41(2), 99-105. http://dx.doi.org/10.2307/1927792

Gordon, M. (1962). The investment, financing, and valuation of the corporation. Homewood: Irwin.

Hallerbach, W. G. (2003). Cross- and auto-correlation effects arising from averaging: The case of US interest rates and equity duration. Applied Financial Economics, 13(4), 287-294. http://dx.doi.org/10.1080/09603100210135720

Ljung, G., \& Box, G. (1978). On a measure of lack of fit in time series models. Biometrika, 65(2), 297-303. http://dx.doi.org/10.1093/biomet/65.2.297

MacKinnon, J. G. (1996). Numerical distribution functions for unit root and cointegration tests. Journal of Applied Econometrics, 11, 601-618. http://dx.doi.org/10.1002/(SICI)1099-1255(199611)11:6<601::AID-JAE417>3.0.CO;2-T

Modigliani, F., \& Cohn, R. B. (1979). Inflation, rational valuation, and the market. Financial Analyst Journal, 35, 24-44. http://dx.doi.org/10.2469/faj.v35.n2.24

Nelson, D. B. (1991). Conditional heteroskedasticity in asset returns: A new approach. Econometrica, 59(2), 347-370. http://dx.doi.org/10.2307/2938260

Sweeney, R. (1997). Do central banks lose on foreign-exchange intervention? A review article. Journal of Banking and Finance, 21(11/12), 1667-1684. http://dx.doi.org/10.1016/S0378-4266(97)00033-2

Williams, J. B. (1938). The theory of investment value. Cambridge, MA: Harvard University Press.

\section{Copyrights}

Copyright for this article is retained by the author(s), with first publication rights granted to the journal.

This is an open-access article distributed under the terms and conditions of the Creative Commons Attribution license (http://creativecommons.org/licenses/by/3.0/). 